\title{
Morphological evolution of the fringe-belts of Krasnoyarsk
}

\author{
Elena Logunova \\ Department of Urban Design and Planning, School of Architecture and Design, Siberian Federal \\ University. Russia \\ E-mail: el.lgnv@yandex.ru
}

\begin{abstract}
Urban fringe-belt phenomenon in cities of Siberia hitherto was poorly investigated. Thus, it constitutes an extremely broad research area. Phases and processes of formation, transformation and alienation in urban fringebelts examines at the case of Krasnoyarsk from the 17th to mid 20th centuries. Relation of changes in fringe-belts structure and political and socio-economic contexts is evidently at all periods of their physical formation. Natural fixation lines (topographic features, body of big river, and development of small river valley) and man-made fixation lines (city walls, railway corridor) influenced to the formation and evolution processes of fringe-belts and urban fabric generally. Railway was a turning point in the city expansion and contributed to overcoming of the power natural fixation line as the Yenisei river. Unlike the urban core, right bank of Krasnoyarsk formed as a linear city with specific fringe belts. Detailed analysis of Krasnoyarsk city plan indentifies several morphological units separated by fringe-belts. These fringe-belts are characterized by distinctive road network, variety of land-use units and heterogeneous forms in plan. It presents difficulties for reconstruction projects of modern city. An approach for renovation of these territories needs to depend on urban morphology methodology.
\end{abstract}

Keywords: Fringe-belt, Siberia, urban morphology, fixation line.

\section{Introduction}

The fringe-belt concept is one of the most important concepts in urban morphology which provides a possibility to analyze existing urban layout. Currently Fringe belts evolution of cities of Europe, China, New Zealand and Brazil have been the focus of attention of urban morphologists and had been studied in detail. Urban fringe-belt phenomenon in cities of Siberia hitherto was poorly investigated. Thus, it constitutes an extremely broad research area. In this example it seems to be interesting to clarify an influence of cultural, political and economic contexts to the formation processes, structure and land uses of fringe belts in Siberian cities.

The emergence of cities in Siberia is one of the most important periods in the history of
Russia associated with the assimilation policy of the Siberian territories and was occurring in several stages. As a result, the arising of cities was unspontaneous process and took place under strict state control. It affected on the choice of the places of cities foundation and the initial planning structures. Wooden walls of burgs as a means of fortification were a characteristic feature of Siberian settlements at the 17th century and served as a fixation line that affected to the origin of fringe belts land uses beyond its borders. In subsequent periods there was a dependence of the changes in the structure of fringe belts from the administrative status of cities, industries and topographical conditions.

There are several key stages in historical and geographical development of Krasnoyarsk from the time of city's foundation to becoming as a major Siberian city. These stages affected 
to the formation of Krasnoyarsk fringe belts in particular and the morphological structure of the city in general.

Topographic features of the territory had been determining the compact city structure for four centuries and restraining the development of urban fabric within the boundaries of one landscape zone. This factor gave a distinctive parameters to fringe belts.

\section{Methodology}

Analysis of the historical and geographical development of Krasnoyarsk morphological structure was carried out on the basis of archival materials, surviving descriptions of the city in different historical periods, comparison of the fixation city plans $(1701,1748,1894,1902$, 1906) and city plans (1774, 1828, 1898, 1924, 1934) and of land use analysis.

\section{Measurement and analysis}

The emergence of Krasnoyarsk in 1628 as a military burg is associated with the first stage of Siberian lands development. Krasnoyarsk burg was erected on a high pointed cape at the confluence of the small river Kacha into river Yenisei that surrounded on the west by the Afontova Hill and in the north by the Karaulnaya Hill along the left bank of Kacha. The planning structure of the Krasnoyarsk small burg was as an irregular quadrangle measuring 100 by 120 meters following the natural outline of the cape.

Krasnoyarsk burg walls acted as a fixation line for the city's growth and provoked the appearance of fringe land uses like in many medieval cities in Europe and China, surrounded by walls. At the first decades after the burg formation a shortage of land resources within the city walls has led to the placement of agricultural lands outside of the city walls and to a chaotic housing development that was concentrated along the main transport routes according to the surviving descriptions. However, cartographic evidence of this information doesn't exist.

Cartographically fixed fringe land uses arose in connection with the increase of population, the appearance of the trading quarter and the second row of city walls in 1659 . The unclosed structure was the feature of the second burg wall. The fortifications of the trading quarter were absent from the south, from the side of the Yenisei. This is due to the fact that the large river and steep bank served as a means of fortification and also as a powerful natural fixation line for the city development, which was insurmountable at the early stages of Krasnoyarsk formation. Subsequently, forge and several enterprises were located along the banks of the Yenisei river forming partly a fringe belt, that didn't left any imprint at the city morphological structure.

The inner fringe belt of the late 17th-mid18 th centuries was formed outside the burg in the north of the city wall and on the left bank of the Kacha, under the slope of the Karaulnaya Hill. This inner fringe belt is visible clearly in the modern structure of Krasnoyarsk. In 17thmid-18th centuries inner fringe belt included small skinnery, soap and candle enterprises, stockyards and chaotic suburban residential development of the Zakachinskaya Sloboda. The following mention of contemporary are encountered about it: "... some of the others still lived ... over the Kacha river in spate of the city plan "... (near the road to Yeniseisk city)" [ ]. This quotation emphasizes the characteristic spontaneity and unregulated occurrence of fringe belt, revealed in the studies of M.R.G. Conzen (1960) and J. W. R. Whitehead (1988). By the end of the 18 century many Siberian settlements including Krasnoyarsk had loosed their military-defensive significance. The wooden burg was preserved as a planning element of the city structure.

The fire of 1773 became a turning point in the city development of Krasnoyarsk, introducing own corrections into urban growth. The period of post-fire restoration and the slump in the urban sprawl provoked the emergence of the western fringe belts of the late 18 th century and early 19 th centuries. The urban free-pattern that had been formed before that time was destroyed completely with all the fortifications. A regular rectangular grid of streets with proportions characteristic only for Krasnoyarsk and its historical and 
topographical conditions was laid. Street blocks - "kurtina"- were adopted as a structural unit of the city plan with dimensions of $150 \mathrm{x}$ 270 meters and $125 \times 250$ meters.

In the city's new plan, the dependence of the tracing of streets from urban fortifications was red that was marked by M.P.G. Cozen (1960). There was the originated of the consequent street along the lost western wall line, according to his terminology. The same processes of the dependence of the streets emergence from city walls were revealed and studied in numerous Russian investigations (Bondarenko I. A., Mazur L. D., Rappoport P. A., Tzarev V. I.).

The placement of religious institutions took place on the periphery of the city in accordance to the established urban traditions. The Vsechsvyatskaya Church and the nearby cemetery that functioned until the 1820 s, the prison and the preserved natural forest on the bank of the Yenisei formed the fringe belt of the 18th and early 19th centuries. At the end of the 18th century, the western fringe belt of the 18 th and early 19th centuries formed with the fringe belt of the 17th and mid-18th centuries an almost continuous structure bounded from the south and east by water arteries and relief. At this stage the fringe belt of the 17 - the middle of the 18th centuries entered to the stage of a functional consolidation and a physical growth along the base of the Karaylnaya Hill. There was a number of manufacturing enterprises, warehouses, mills and non-regulated residential houses. The free plan configuration and uneven street network of the fringe belt 17 - the middle of the 18th became particularly evident in contrast to the regular urban fabric of the city of the late 18 th century. Also, the processes of alienation were noted that occurred in the 20th century. The comprehensive secondary school mill and residential houses were built on the site of the mill. By the 21st century, communal and economic facilities and warehouses define the main functional saturation of the fringe belt of 17 - the middle of the 18 th centuries.

The fringe belt of the late 18th and mid19th centuries
In 1822 Krasnoyarsk became the administrative and trading center of the Yenisei Governorate. This fact served as the next impetus for the modifications of Krasnoyarsk morphological structure. The phase of active urban growth and residential development has came and the area of the western fringe belt of the late 18th and mid-19th centuries embedded the city structure. The processes of morphological, functional transformations of the fringe belt of the late 18th and mid-19th centuries have been beginning by this moment. The transfer of the central core of Krasnoyarsk has occurred that previously occupied an eccentric position on the site of the lost small burg.

Due to the lack of land in the existing city center, commercial and public institutions there were transferred to the periphery of the city. The new city center was located within the boundaries of the fringe belt of the late 18th and mid-19th centuries and entails the appearance of trading rows, the BogoroditseRozhdestvensky Cathedral, Novobazarnaya Square (later renamed the Revolution Square) and residential buildings.

From the middle of the 19th century to the middle of the 20th century, functional transformations continued to occur in the western fringe belt of the late 18th and mid19 th centuries. The House of Soviets (now the Government of the Krasnoyarsk Region) was built on the site of the BogoroditseRozhdestvensky Cathedral, in the mid20th century the Kvant plant replaces the Vsechsvyatskaya Church with the subsequent placement of commercial spaces in the $21 \mathrm{st}$ century. This is commercialization processes of the fringe belt are evident. Despite the fact that these processes occur differently in the socialist system, this phenomenon confirms the economic theory of urban fringe belt development J. Whitehead. There was the garrison military hospital, the regional library, the secondary school. The alienation processes of the fringe belt are observed along the embankment of the Kacha, where there was a residential development.

The planning structure of the fringe belt of the late 18th and the mid-19th centuries is clearly reading in a modern urban fabric. Despite the fact that it was embedded in the 
city structure and planned according to regular principles, The size of plots is allocated against the background of the adopted single module of blocks. The large natural site of the forest, which became an city garden and the territory in the north from it are embedded in an urban fabric in parameters twice exceeding the "kurtina". There is a distinctive street pattern inside the boundaries of the fringe belt and the street-road network is characterized by less intensive traffic. Currently, a large number of green and public spaces (Gorky Central Park, Revolution Square, Surikov Square and Garden named

G.V. Yudin on the left bank of the Kacha) emphasizes the former fringe position of the central territory. There is a low density of buildings with the dominance of administrative, social and warehouse buildings.

The prison area has also undergone functional transformation. The Theater Square was at this place in the middle of the 19th century and the Lokomotiv stadium was laid in the second half of the 20th century.

\section{The fringe belt of the late 19th and early 20th centuries}

The fire of 1883 was the precondition for the formation of the fringe belt in the late 19th and early 20th centuries. Krasnoyarsk was built mainly of wooden buildings and was again destroyed completely by fire. It again delayed urban development.

By this time, the city's border approached the western topographic fixation line as Afontovo Hill.

At the foot of the Afontovo Hill begins to developed fringe land uses. The decision of the city authorities to forbid a wooden construction in the historic part of the city and speculation with the land affected to spontaneous localization of wooden buildings at the periphery. Wooden buildings retained traditional manor character, differing from a new stone building of the center. The displaced prison, the parish school, the Parade Square (modern Red Square) and Ostrozhnaya Square, the Alexander Nevsky military church and the soldier's settlement were concentrated simultaneously with the wooden houses under the slope of Afontova Mountain. In the middle of the 20th century the radio plant was established on the site of The Alexander Nevsky military church.

The urban fabric of the city undergoes a new wave of transformation with the construction of the Trans-Siberian Railroad in 1895. The railway line stretched in the meridional direction at the west of the existing building and on the path of its supposed development. The fringe belt of the late 19th and early 20th centuries, which was poorly formed up to that time, was fixed by the strip of the railroad diversion. The railway corridor became as structural and planning axis of the development and attracted the location of the railway station, railway workshops and warehouses. Thus, a large zone of the "false" fringe belt was fixed at the foot of Afontovo Hill. Since the first decade of the 20th century these territories were included in the city boundaries. In the future, this zone will continues to be filled with fringe belt functions. There are a military camp, a brick factory, a combine harvester food base and numerous manufacturing and storage facilities. The growth of the population (in the period from 1897 to 1923 the number of inhabitants of the city increased from 26,700 to 60,400 people) was accompanied by the development of the following landscape terraces Afontovo and Karaulnaya Hills. New urban areas Nikolaevskaya, Alekseevskaya and Pokrovskaya sloboda gave Krasnoyarsk the forms of disperse development.

The construction of the railway bridge in 1899, which connected the left and right banks of the Yenisei River contributed to overcoming the powerful natural fixation line. Krasnoyarsk found a dismembered structure of the plan that is actively developing at the present time.

A concentration of fringe belt land uses along the right bank of the Yenisei and the railway line are marked. Since by 1924 . a brick factory, a timber mill, a paper mill, and a halt-harbor appear are appeared at this place.

At the beginning of the 1930s the government adopted a resolution about the concept of the industrial Krasnoyarsk development. It provided for the formation of the city as an 
industrial center and the emergence of new urban and social forms. In this connection, the Master Plan of the City of 1934 solved the tasks of locating the main heavy industrial production and functional zoning of the right bank of the Yenisei. At the same time, free access to the Yenisei was provided single, undivided residential areas and its coastal zone was designed in the form as a wide range of gardens and parks. It also presumed for the removal of the railway to the foot of the mountains, which at that time divided the right bank into two parts. But, as practice has shown, the set of existing factors led to the disagreement between the designed plan and the backlog of a number of adopted principles for implementing of the Krasnoyarsk Master Plan. The consequence was the origin of spontaneously emerged, contrary to the Master Plan of the city, unplanned land uses patterns that formed the fringe belt of the 20th century. It had a significant impact to the morphological structure of the right bank of Krasnoyarsk.

The railway tracks, which remained at their former location, and the Yenisei River as a main transport arteries, production resources and fixation lines attracted the unsettled location of industrial productions. As a result, the residential areas of the right bank were separated from the Yenisei, in spite of the adopted design decisions. The natural and man-made fixation lines the Yenisei and the railway corridor became the key factor that determined the linear character of the fringe belt of the 20th century. The fringe belt of the 20th century include the Krasnoyarsk Machine Building Plant, the Pulp and paper mill, a cement plant, a timber processing industry, manufacturing and storage facilities.

Large production complexes provoked the formation of associated residential areas and workers' settlements. For a short period from 1931 to 1939 . The number of city residents increased from 82,800 to 186,100 people. The new linear city was formed from residential blocks of the right bank for several years. This was an alternation of residential areas and extensive parts of the fringe belt, that divided urban fabric into several connected poorly territories, presenting a serious problem for the functioning of a modern city.
Currently, morphological structure of Krasnoyarsk is a segregated spatial structure, divided into several morphological regions by obvious fringe belts. Fringe belt were formed spontaneously under the influence of political, social, administrative, economic and technogenic factors.

\section{Conclusion}

The conducted study of the fringe belts of Krasnoyarsk confirms the phenomenon of urban fringe belts in different cultural contexts. A number of distinctive features of Krasnoyarsk fringe belt are revealed as a result of evolution analysis. It is a spontaneity of occurrence, a low density of buildings, a complicated land uses, a low density of street network.

Urban fringe belts of Krasnoyarsk have a number of specific features, which are primarily due to the landscape characteristics of the city (Fig. 1). Topographical fixation lines predetermined the origin and shape of the most read distinctly the fringe belt of the 17th-mid-18th centuries and the fringe belt the mid-19th-early 20th centuries and the 20th century. For these fringe belts the concentric configuration of the plan is not typical. During the period of the city's formation, fringe land uses consolidated their position along the slopes of Afontovo Hill and Karaulnaya Hill. The loss of city walls as a fixation line for the fringe belt of the late 18th and mid-19th centuries and inclusion to the central part of the city determined exposure to the processes of functional transformations. At the moment, the functional saturation of the fringe belt of the late 18th and mid-19th centuries meets the needs of the city center and plays an important recreational and administrative significance for the whole of Krasnoyarsk.

There is a partial fusion of the fringe belt of the late 18th and mid-19th centuries with the fringe belt of the mid-17th to the mid18th centuries into a single structure. Similar phenomena are also observed in the Turkish city of Mersin (Unlu, 2013).

Linear industrial fringe belts of the 20th century on the right bank of the Yenisei River is represented complexity for the renovation process of the modern city. 


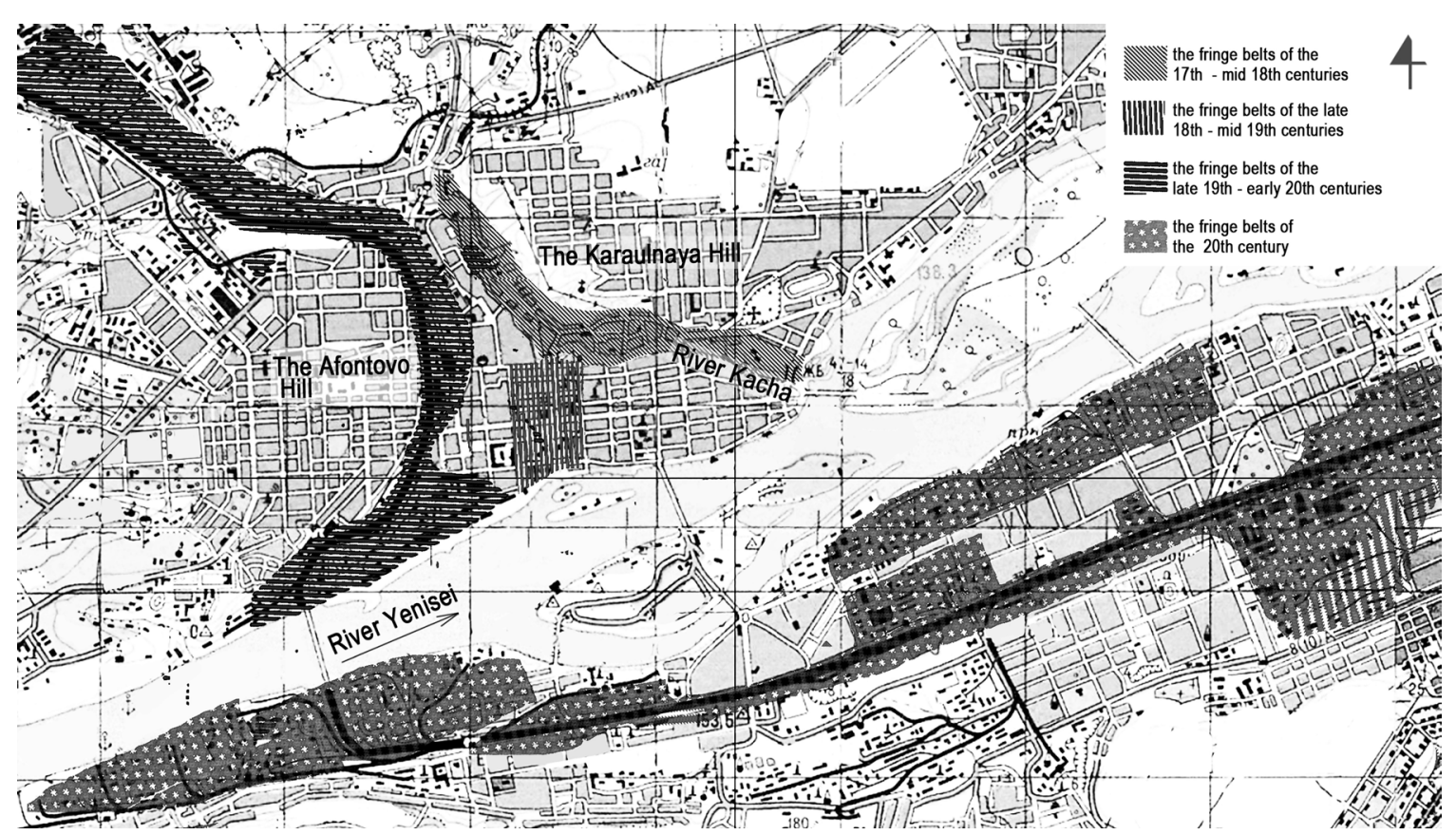

Figure 1. Fringe belts of Krasnoyarsk

Because it contributed to a fundamental change in the physical characteristics of the city. If the fringe land use along the railway line as a man-made fixation line retains its character, then the fringe belt along the Yenisei coast is a subject of alienation processes. These territories are occupied by the residential development zones. In this case, the design and placement of residential areas occurs locally without considering the fringe belt as a single interconnected structure. The lack of attention among designers to the concept of fringe belts and the historical prerequisites of origins and features of distinctive land uses excludes the possibility of adopting coordinated projects for the reconstruction of a modern city and complicates their implementation.

\section{References}

Conzen, M.R.G. (1960) Alnwick, Northumberland: a study in town-plan analysis Institute of British Geographers Publication 27 (George Philip, London)

Kukina, I.V. (2006) 'Fringe territories of Siberian cities', Architectural Heritage (ComKniga, Moscow) 46, P. 289-97

Tsarev V. I. (2011) Urban planning of Siberia

(Kolo, St. Petersburg).
Unlu Ë T (2013) 'Thinking about urban fringe belts: A Mediterranean perspective'. Urban Morphology 17, 5-20.

Whitehand, J.W.R (1966) 'Fringe belts: a neglected aspect of urban geography' Transactions of the Institute of British Geographers 41 pp. 223-33.

Whitehand, J.W.R. (1988) 'Urban fringe belts: development of an idea', Planning Perspectives 3, 47-58.

Whitehand, J.W.R., Morton, N.J. (2003) 'Fringe Belts and the Recycling of Urban Land: An Academic Concept and Planning Practice', Environment and Planning B: Planning and Design, 30, 819-39.

Whitehand J.W.R, Gu K. and Whitehand S.M. (2011) 'Fringe belts and socio-economic change in China' Environment and Planning B: Planning and Design 38: 41-60. 